\title{
Termite-killing components in Serratia marcescens (SM1)
}

\author{
Renjie Fu ${ }^{1,2} \cdot$ Jian Luo ${ }^{1,2} \cdot$ Kai Feng ${ }^{1,2} \cdot$ Xiaoyu Lu ${ }^{1,2}$. \\ Fang Tang ${ }^{1,2}$
}

Received: 29 December 2019 / Accepted: 18 March 2020 / Published online: 25 June 2020

(C) The Author(s) 2020

\begin{abstract}
The bacteria, Serratia marcescens (SM1) was previously obtained from the black-winged termite, Odontotermes formosanus Shiraki. SM1 was highly toxic to $O$. formosanus, however, the mechanism of toxicity is unclear. In this study, toxicity test results showed that the main components that affected $O$. formosanus were in a supernatant and that the insecticidal protease in the supernatant resulted in the death of $O$. formosanus. In addition, zinc sulphate recovery experiments indicated that the metalloproteinases in the supernatant were more harmful. These results provide a theoretical foundation for the future biological control of termites, the basis for the development of pest control technology and the discovery of new pesticides.
\end{abstract}

Keywords Odontotermes formosanus Shiraki $\cdot$ Serratia marcescens strain SM1 · Supernatant · Protease · Metalloproteinases

Project funding: This research was supported by Zhenjiang's Key R\&D Program-Modern Agriculture (NY201702), Jurong Agricultural Science and Technology support plan (NY2017846771) and the Priority Academic Program Development Fund of Jiangsu Higher Education Institutions.

The online version is available at http://www.springerlink.com

Corresponding editor: Yu Lei.

Fang Tang

tangfang76@foxmail.com; tangfang76@sohu.com

1 Co-Innovation Center for the Sustainable Forestry in Southern China, Nanjing Forestry University, Nanjing 210037, People's Republic of China

2 College of Forestry, Nanjing Forestry University, Nanjing 210037, People's Republic of China

\section{Introduction}

Termites damage buildings reservoir dams and other structures made of wood, agricultural and forestry crops, and cable transportation facilities(Cosme et al. 2020; Dahlsjo et al. 2020; Djuideu et al. 2020; Du et al. 2020), and hazardous areas account for approximately $50 \%$ of the global area. Termites live in social groups and their resistance to natural enemies and adverse environmental factors is greatly enhanced due to their group defense function. In addition, the secluded nature of termites makes them more difficult to study and control. Therefore, the prevention and treatment of termite infestations has always been a challenge of pest management (Zhang et al. 2015). At present, the most common and important way to control termites is to use chemical agents (Sapkota et al. 2020). The advantage of this approach is that it is effective, but chemical pesticides pose considerable threat to the environment and to human health, including causing pesticide poisoning, cancer, deformities in children and gene mutation (Liu et al. 2010). With increasing awareness of the need for safety and environmental protection, these chemical termite control agents will eventually be eliminated. Compared with chemical controls, biological control is environmentally safe and durable, and avoids the problems caused by chemicals. It is foreseen that biological control methods will become the mainstream of future control work.

Serratia marcescens is a rod-shaped, anaerobic, gramnegative bacterium of the family Enterobacteriaceae. It is generally smaller than other intestinal bacteria, without capsules and occasionally with long filaments (Hejazi and Falkner 1997). It is commonly found in water, plants, animals and soil, and produces a secondary metabolite-prodigiosin-in the process of growth (Montaner and PerezTomas 2003). S. marcescens is pathogenic to many insects, 
including the cotton bollworm, Helicoverpa armigera Hüber (Chen et al. 2005), Myrmeleotettix palpalis (Jin et al. 2005), Phyllotreta striolata (Yang et al. 2014), the tobacco cutworm, Spodoptera litura Fabricius (Niu et al. 2015; Aggarwal et al. 2017), S. exigua (Niu et al. 2015), and the larvae and eggs of the Asian palm weevil, Rhynchophorus ferrugineus Oliver (Zhang et al. 2011). Secretory product of $S$. marcescens, prodigiosin, have also been found to be pathogenic to some organisms, such as Bursaphelenchus xylophilus (Hu et al. 2017), the yellow fever mosquito, Aedes aegypti L. and the Indian malaria mosquito, Anopheles stephensi Liston (Patil et al. 2011). Niu et al. (2018) used $S$. marcescens mixed with five insecticides to treat Laodelphax striatellus and found that the mortality rate of $L$. striatellus to the insecticides could be improved. It is clear that $S$. marcescens is pathogenic to many types of pests and has wide market prospects in biological control.

Our laboratory recently isolated a red pigment-producing bacterium from dead termites and identified it as Serratia marcescens (SM1) (Fu et al. 2019). SM1 was significantly toxic to $O$. formosanus (Fu et al. 2020), but the specific components and mechanisms of this toxicity need further examination. Research has shown that the pathogenesis of $S$. marcescens is due to chitinase enzymes (Regev et al. 1996; Zhang et al. 2000; Xu and Peng 2004; Yin et al. 2004; Jin et al. 2005), and Tao 2006 has reported that the insecticidal protein of $S$. marcescens is a metallic protein that exists in a supernatant of the bacteria. However, the active components of $S$. marcescens that are toxic to termites have not been identified. The purposes of this study are: (1) to clarify the termite-killing components of S. marcescens; and, (2) to provide a basis for the biological control of termites.

\section{Materials and methods}

\section{Insects}

Six colonies of Odontotermes formosanus were collected from Jurong in Zhenjiang, Jiangsu Province, China. Termites
Culture and concentration determination of the $S$. marcescens strain, SM1

SM1 was isolated from infected $O$. formosanus and deposited at Nanjing Forestry University, Nanjing. A solid bacterial medium $(1 \mathrm{~L})$ was prepared, consisting of $10 \mathrm{~g}$ peptone, $20 \mathrm{~g}$ beef extract, $2 \mathrm{~g} \mathrm{NaCl}, 2 \mathrm{~g} \mathrm{~K}_{2} \mathrm{HPO}_{4}, 18 \mathrm{~g}$ agar and $1 \mathrm{~L}$ $\mathrm{H}_{2} \mathrm{O}$ with $\mathrm{pH}$ 7.2-7.4. A seed medium (1 L) of $10 \mathrm{~g}$ peptone, 20 g yeast extract, $2 \mathrm{~g} \mathrm{NaCl}, 2 \mathrm{~g} \mathrm{~K}_{2} \mathrm{HPO}_{4}$ in $1 \mathrm{~L}$ of $\mathrm{H}_{2} \mathrm{O}$ was also prepared. A zymotic medium $(1 \mathrm{~L})$ was prepared of $10 \mathrm{~g}$ peptone, $30 \mathrm{~g}$ soybean oil, $2 \mathrm{~g} \mathrm{NaCl}, 2 \mathrm{~g} \mathrm{~K}_{2} \mathrm{HPO}_{4}$ in I $\mathrm{L} \mathrm{H}_{2} \mathrm{O}$. As the amount of SM1 increased, its optical density at $600 \mathrm{~nm}\left(\mathrm{OD}_{600}\right)$ also increased. The $\mathrm{OD}_{600}$ value was linearly related to the number of $S$. marcescens SM1 bacteria and used to determine the bacterial count of the liquid culture. To obtain the concentration of the S. marcescens $\mathrm{SM} 1$ suspension, the $\mathrm{OD}_{600}$ value was measured on a spectrophotometer.

\section{Bioassay of components of $S$. marcescens SM1 fermentation}

The concentration of the fermentation medium of $S$. marcescens SM1 was $1.17 \times 10^{10}$ cells $/ \mathrm{ml}$, and the fermentation medium of $S$. marcescens SM1 was centrifuged at $5000 \mathrm{r}$ for $20 \mathrm{~min}$ at $4{ }^{\circ} \mathrm{C}$. After centrifugation, a surface oil liquid (pigment layer), a middle layer supernatant and a lower layer of bacterial precipitate were obtained. The lower layer of the bacteria precipitate was dissolved by medium. According to the transfer toxicity method (Tang et al. 2007), quality filter paper was first wetted, placed in a 9-cm diameter glass Petri dish, and five $O$. formosanus worker termites were dipped in each treatment solution. Five soaked termites marked in red on the abdomen and twenty untreated worker termites were placed in the culture dish. The five marked worker termites dipped in the medium and the 20 untreated worker termites were the controls. The termites were observed and recorded in darkness at $25^{\circ} \mathrm{C}$. The experiment group and the control groups were repeated three times in the same manner.

Corrected mortality rate treatment $(\%)=\left(\right.$ mortality rate $_{\text {treatment }}-$ mortality rate $\left._{\mathrm{ck}}\right) /\left(100-\right.$ mortality rate $\left._{\mathrm{ck}}\right) \times 100$

were kept in sealed plastic containers in total darkness at $27 \pm 1^{\circ} \mathrm{C}$ and $75 \pm 1 \%$ relative humidity. All colonies were maintained under laboratory conditions without soil and with moist filter paper for one day before the subsequent experiments.

\section{Effect of protease inhibitors on the bioassay of the SM1 fermentation}

Bioassay of components of $S$. marcescens SM1 fermentation showed that the culture supernatant of the bacterial fermentation had a strong toxicity to $O$. formosanus. Therefore, the supernatant was treated separately with proteinase $\mathrm{K}$ at $50 \mu \mathrm{g} / \mathrm{ml}$, ethylenediaminetetraacetic acid (EDTA) at $10 \mathrm{mmol} / \mathrm{L}, 1,10$-phenanthroline at $10 \mathrm{mmol} / \mathrm{L}$, and 
phenylmethanesulfonyl fluoride (PMSF) at $1 \mathrm{~m} \mathrm{~mol} / \mathrm{L}$. There was also a treatment without reagents added and was only heated at $60^{\circ} \mathrm{C}$ for $15 \mathrm{~min}$. The toxicity assay was then performed using the transfer toxicity method. The five marked worker termites dipped in the medium and the 20 untreated worker termites were the controls. The experimental groups and the control groups were assayed three times.

\section{Recovery experiment of $\mathrm{ZnSO}_{4}$}

After the bioassays using the supernatant treated with different protease inhibitors, the supernatants treated with the two types of protease inhibitors, EDTA and 1,10-phenanthroline, were subjected to zinc sulphate $\left(\mathrm{ZnSO}_{4}\right)$ recovery treatments. The two supernatants were incubated with $\mathrm{ZnSO}_{4}$ at a concentration of $0.5 \mathrm{mmol} / \mathrm{L}$ for $1 \mathrm{~h}$ at $22^{\circ} \mathrm{C}$, and the same toxicity assay performed again. The medium incubated at $22{ }^{\circ} \mathrm{C}$ for $1 \mathrm{~h}$ with a concentration of $0.5 \mathrm{~m} \mathrm{~mol} / \mathrm{L} \mathrm{ZnSO}_{4}$ was the control. The concentration of the SM1 fermentation was $1.69 \times 10^{10} \mathrm{cells} / \mathrm{ml}$ and the toxicity assay was then performed using the transfer toxicity method. The experimental group and the control group were independently assayed three times.

\section{Statistical analysis}

The results were subjected to an analysis of variance (ANOVA) using InStat software (GraphPad, San Diego, CA, USA) with a level of significance at $P<0.05$. Tukey's test was used for multiple comparisons.

\section{Results}

\section{Bioassay of components of the SM1 fermentation}

The transfer toxicity bioassay against $O$. formosanus was carried out using the components of the SM1 fermentation. The results show that the toxicity of the components was not different from that of the supernatant $(P>0.05)$. After $36 \mathrm{~h}$, the corrected mortality rate of the supernatant was approximately $50 \%$, and at $54 \mathrm{~h}$, the rate was close to $80 \%$. After
$54 \mathrm{~h}$, toxicity of the lower bacterial layer was relatively poor at only $28.5 \%$. Among the three components, the uppermost oil pigment layer had the poorest toxicity (Table 1).

\section{Effect of protease inhibitors on the bioassay of SM1 fermentation}

After the middle layer supernatant was identified as the main active component, it was treated with protease inhibitors. It was first heated at $60^{\circ} \mathrm{C}$ for $15 \mathrm{~min}$ to denature the protease. The results show that the toxicity effect of the supernatant decreased significantly $(P<0.05)$ after heating; the toxicity became stronger after $48 \mathrm{~h}$ and the corrected mortality reached $60 \%(P>0.05)$. Four different protease inhibitors, PMSF, EDTA, proteinase $\mathrm{K}$ and 1, 10-phenanthroline, were added separately to the supernatant. The results show that the toxicity decreased when protease inhibitors were used. When proteinase $\mathrm{K}$ was used, the toxicity of the supernatant decreased most, and the corrected mortality rate was $10.4 \%$ at $54 \mathrm{~h}$; when EDTA was used, the toxicity of the supernatant was greatly reduced, and the corrected mortality rate was $22.4 \%$ at $54 \mathrm{~h}$; when PMSF or 1, 10-phenanthroline was used, the toxicity of the supernatant was reduced, and the corrected mortality rate failed to reach $50 \%$ by $54 \mathrm{~h}$ (Table 2).

\section{Recovery experiment of $\mathrm{ZnSO}_{4}$}

After protease inhibitors suppressed the toxicity of the SM1 fermentation supernatant, it was blocked by two inhibitors of metalloprotease and was subjected to a $\mathrm{ZnSO}_{4}$ recovery experiment. This could confirm that the protease in the supernatant was toxic to $O$. formosanus and could initially indicate what the active protease was. There was no difference in toxicity between the medium and the medium treated with $0.5 \mathrm{~m} \mathrm{~mol} / \mathrm{L} \mathrm{ZnSO}_{4}$, neither of which can caused the death of termites. The EDTA-treated supernatant had an increase in insecticidal activity after the $\mathrm{ZnSO}_{4}$ recovery test $(P<0.05)$. At $54 \mathrm{~h}$, the corrected mortality increased from 23.6 to $44.4 \%$. In addition, the insecticidal activity of the 1 , 10-phenanthroline-treated supernatant was improved after the $\mathrm{ZnSO}_{4}$ recovery experiment, and the corrected mortality

Table 1 Toxicity test results of different components of SM1 fermentation against $O$. formosanus (transfer toxicity method)

\begin{tabular}{|c|c|c|c|c|c|c|c|c|c|}
\hline \multirow[t]{2}{*}{ Group } & \multicolumn{9}{|c|}{ Corrected mortality rate $(\%)$} \\
\hline & $6 \mathrm{~h}$ & $12 \mathrm{~h}$ & $18 \mathrm{~h}$ & $24 \mathrm{~h}$ & $30 \mathrm{~h}$ & $36 \mathrm{~h}$ & $42 \mathrm{~h}$ & $48 \mathrm{~h}$ & $54 \mathrm{~h}$ \\
\hline Whole fermentation & $6.8 \pm 5.9 a$ & $18.5 \pm 7.4 \mathrm{a}$ & $22.5 \pm 3.4 \mathrm{a}$ & $29.8 \pm 1.9 \mathrm{a}$ & $39.6 \pm 9.2 \mathrm{a}$ & $53.6 \pm 4.0 \mathrm{a}$ & $66.5 \pm 2.5 \mathrm{a}$ & $68.3 \pm 11.2 \mathrm{a}$ & $81.7 \pm 5.5 \mathrm{a}$ \\
\hline Supernatant & $1.8 \pm 0.0 \mathrm{a}$ & $17.0 \pm 6.1 \mathrm{a}$ & $24.1 \pm 2.7 \mathrm{a}$ & $24.3 \pm 6.9 \mathrm{a}$ & $43.6 \pm 3.3 \mathrm{a}$ & $49.7 \pm 8.4 \mathrm{a}$ & $60.9 \pm 7.1 \mathrm{a}$ & $68.1 \pm 6.4 \mathrm{a}$ & $79.5 \pm 4.0 \mathrm{a}$ \\
\hline Oil pigment & $0 \mathrm{a}$ & $3.3 \pm 2.9 \mathrm{a}$ & $1.7 \pm 2.9 b$ & $3.3 \pm 5.8 b$ & $3.5 \pm 3.0 \mathrm{~b}$ & $1.8 \pm 3.0 \mathrm{c}$ & $1.8 \pm 3.0 \mathrm{c}$ & $13.9 \pm 2.4 \mathrm{c}$ & $16.3 \pm 3.3 \mathrm{c}$ \\
\hline Bacterial precipitation & $3.3 \pm 2.9 \mathrm{a}$ & $5.0 \pm 5.0 \mathrm{a}$ & $10.3 \pm 4.9 b$ & $17.5 \pm 2.2 \mathrm{a}$ & $23.8 \pm 7.1 \mathrm{a}$ & $24.0 \pm 11.2 \mathrm{~b}$ & $25.9 \pm 8.1 b$ & $25.7 \pm 11.4 \mathrm{~b}$ & $28.6 \pm 3.2 b$ \\
\hline
\end{tabular}

Different letters in the column indicate significant differences $(P<0.05)$ 
Table 2 Toxicity test results of the supernatants treated with different protease inhibitors against $O$. formosanus (transfer toxicity method)

\begin{tabular}{|c|c|c|c|c|c|c|c|c|c|}
\hline \multirow[t]{2}{*}{ Group } & \multicolumn{9}{|c|}{ Corrected mortality rate (\%) } \\
\hline & $6 \mathrm{~h}$ & $12 \mathrm{~h}$ & $18 \mathrm{~h}$ & $24 \mathrm{~h}$ & $30 \mathrm{~h}$ & $36 \mathrm{~h}$ & $42 \mathrm{~h}$ & $48 \mathrm{~h}$ & $54 \mathrm{~h}$ \\
\hline Supernatant & $3.4 \pm 3.0 \mathrm{a}$ & $12.0 \pm 3.5 \mathrm{a}$ & $22.4 \pm 5.7 \mathrm{a}$ & $32.8 \pm 5.8 \mathrm{a}$ & $43.1 \pm 11.2 \mathrm{a}$ & $54.9 \pm 6.2 \mathrm{a}$ & $68.1 \pm 5.6 \mathrm{a}$ & $73.6 \pm 5.9 \mathrm{a}$ & $91.7 \pm 9.6 \mathrm{a}$ \\
\hline Supernatant heating & $0 \mathrm{a}$ & $0 \mathrm{~b}$ & $8.1 \pm 7.6 \mathrm{a}$ & $12.2 \pm 3.1 \mathrm{~b}$ & $27.1 \pm 1.8 \mathrm{~b}$ & $35.0 \pm 5.7 \mathrm{~b}$ & $51.9 \pm 1.6 \mathrm{~b}$ & $60.4 \pm 4.4 \mathrm{a}$ & $75.6 \pm 5.4 \mathrm{~b}$ \\
\hline Proteinase $\mathrm{K}$ & $0 \mathrm{a}$ & $3.3 \pm 2.9 b$ & $6.8 \pm 5.9 \mathrm{a}$ & $6.8 \pm 5.9 b$ & $8.8 \pm 3.7 b$ & $7.2 \pm 0.4 \mathrm{c}$ & $11.0 \pm 4.3 \mathrm{c}$ & $8.1 \pm 9.6 \mathrm{c}$ & $10.4 \pm 4.4 \mathrm{~d}$ \\
\hline PMSF & 0a & $0 \mathrm{~b}$ & $0 \mathrm{a}$ & $8.6 \pm 4.1 b$ & $8.8 \pm 3.7 b$ & $10.8 \pm 0.6 \mathrm{c}$ & $20.2 \pm 5.3 \mathrm{c}$ & $31.7 \pm 7.0 \mathrm{~b}$ & $46.6 \pm 0.0 \mathrm{c}$ \\
\hline EDTA & $1.7 \pm 2.9 \mathrm{a}$ & $1.7 \pm 2.9 b$ & $1.8 \pm 3.0 \mathrm{a}$ & $3.4 \pm 3.0 \mathrm{~b}$ & $5.5 \pm 5.3 b$ & $3.8 \pm 3.3 \mathrm{c}$ & $9.6 \pm 8.9 c$ & $12.0 \pm 0.8 \mathrm{c}$ & $22.4 \pm 3.3 \mathrm{~d}$ \\
\hline 1,10-Phenanthroline & $1.8 \pm 0.0 \mathrm{a}$ & $5.1 \pm 3.3 \mathrm{ab}$ & $6.8 \pm 2.7 \mathrm{a}$ & $13.6 \pm 6.5 b$ & $12.3 \pm 3.7 \mathrm{~b}$ & $12.6 \pm 3.1 \mathrm{c}$ & $20.0 \pm 3.5 \mathrm{c}$ & $23.6 \pm 0.0 \mathrm{bc}$ & $40.7 \pm 6.5 c$ \\
\hline
\end{tabular}

Different letters in the column indicate significant differences $(P<0.05)$

at $48 \mathrm{~h}$ was significantly different from that before the recovery $(P<0.05)$. These results further indicate that particular metalloproteases were present in the supernatant, and these metalloproteases were also one of the effective components responsible for the death of $O$. formosanus (Table 3 ).

\section{Discussion}

Research on biopesticide proteins has been important in the development of biopesticides. Over the past few years, several studies of Bacillus thuringiensis insecticidal protein (Schnepf et al. 1998) have shown that protein crystals produced during sporulation are toxic to many organisms. The expression and structural functions of the protein genes have been studied by McGaughey et al. (1998) and Rajamohan et al. (1998). There are four gene clusters encoding the toxin protein complex in the luminescent bacillus, which makes these bacteria that are symbiotic with entomopathogenic nematodes a member of the microbial insecticide protein family (Bowen et al. 1998). Reports of nematophagous pathogenic bacilli also earlier suggested this symbiosis with entomopathogenic nematodes, and their insecticidal components have a lethal effect on a variety of pests (Forst et al. 1997). Studies have shown that active ingredients that play a major insecticidal role include small molecules (Volgyi et al. 1998), lipopolysaccharides (Smigielski and Akhurst 1995 ) and proteins. A $1.2 \mathrm{~kb}$ gene was obtained from the nematophagous pathogenic bacterium A24, which encodes a $30 \mathrm{kDa}$ insecticidal protein. A few microliters of the fermentation containing the toxic protein can cause the death of insect larvae (Smigielski and Akhurst 1995). Moreover, Clostridium difficile (Barloy et al. 1998) and Bacillus sphaericus (Li et al. 2008) also produce insecticidal proteins which are toxic. Studies have shown that $S$. marcescens secretes several well-known extracellular proteins, including nuclease, phosphatase, hemolysin, iron-containing proteins, chitinase, protease, and lipase (Tao 2006). One or several of these components may become insecticide factors. Therefore, studying the specific components of $S$. marcescens SM1 can help to further clarify its mechanism of action on termites.

The uppermost layer of the pigment oil layer, the middle layer supernatant and the bacterial sediment layer were obtained by centrifugation of $S$. marcescens SM1 fermentation. The results show that the toxicity effect of the supernatant was the best and closest to that of the original fermentation. The toxicity of the bacterial sediment layer was poor and differed from that of the original fermentation. In addition, the pigment oil layer had the least effect, and the

Table 3 The $\mathrm{ZnSO}_{4}$ recovery experiment (transfer toxicity method)

\begin{tabular}{|c|c|c|c|c|c|c|c|c|c|}
\hline \multirow[t]{2}{*}{ Group } & \multicolumn{9}{|c|}{ Corrected mortality rate $(\%)$} \\
\hline & $6 \mathrm{~h}$ & $12 \mathrm{~h}$ & $18 \mathrm{~h}$ & $24 \mathrm{~h}$ & $30 \mathrm{~h}$ & $36 \mathrm{~h}$ & $42 \mathrm{~h}$ & $48 \mathrm{~h}$ & $54 \mathrm{~h}$ \\
\hline EDTA & $0 \mathrm{a}$ & $0 \mathrm{a}$ & $3.4 \pm 3.0 \mathrm{a}$ & $5.1 \pm 3.3 b$ & $5.5 \pm 5.3 b$ & $6.8 \pm 5.9 b$ & $10.8 \pm 0.6 b$ & $12.0 \pm 0.8 \mathrm{c}$ & $23.6 \pm 3.0 \mathrm{~b}$ \\
\hline 1,10-Phenanthroline & $1.8 \pm 0.0 \mathrm{a}$ & $3.3 \pm 2.9 \mathrm{a}$ & $8.1 \pm 7.6 \mathrm{a}$ & $12.6 \pm 3.1 \mathrm{ab}$ & $12.0 \pm 0.8 \mathrm{ab}$ & $13.6 \pm 6.5 \mathrm{ab}$ & $20.2 \pm 5.3 \mathrm{ab}$ & $22.4 \pm 3.3 \mathrm{c}$ & $43.6 \pm 3.3 \mathrm{a}$ \\
\hline $\begin{array}{l}\text { EDTA; toxicity recov- } \\
\text { ered after } \mathrm{ZnSO}_{4} \\
\text { addition }\end{array}$ & $3.4 \pm 3.0 \mathrm{a}$ & $3.4 \pm 3.0 \mathrm{a}$ & $8.6 \pm 4.1 \mathrm{a}$ & $8.8 \pm 3.7 b$ & $20.2 \pm 5.3 \mathrm{ab}$ & $23.6 \pm 0.0 \mathrm{a}$ & $27.1 \pm 1.8 \mathrm{a}$ & $35.0 \pm 5.7 b$ & $44.4 \pm 5.3 \mathrm{a}$ \\
\hline $\begin{array}{l}\text { 1,10-Phenanthroline; } \\
\text { toxicity recovered } \\
\text { after } \mathrm{ZnSO}_{4} \text { addition }\end{array}$ & $0 \mathrm{a}$ & $5.1 \pm 3.3 \mathrm{a}$ & $12.0 \pm 3.5 \mathrm{a}$ & $17.5 \pm 2.2 \mathrm{a}$ & $24.0 \pm 11.2 \mathrm{a}$ & $12.6 \pm 3.1 b$ & $31.7 \pm 7.0 \mathrm{a}$ & $55.0 \pm 6.2 \mathrm{a}$ & $55.0 \pm 6.2 \mathrm{a}$ \\
\hline
\end{tabular}

Different letters in the column indicate significant differences $(P<0.05)$ 
mortality rate of $O$. formosanus treated with the pigment oil layer was very close to that of the controls. Therefore, it was confirmed that the main active component of $S$. marcescens SM1 fermentation was in the supernatant, and that the pigment oil layer had no insecticidal properties. Since the bacterial precipitate was added to the medium during dissolution, the undestroyed cells might continue to ferment to produce $S$. marcescens SM1 fermentation and induce a poisoning effect in the subsequent toxicity test experiments.

After identifying that the main active component was the supernatant, it was necessary to further clarify whether the active component was a protease by heating or adding different protease inhibitors. From the results, the toxicity effect of the heated supernatant was significantly reduced, and the corrected mortality rate of the treatment was only $30 \%$. But as time increased, its toxicity gradually increased, which may be caused by the recovery of certain denatured proteases. Since protease K can inhibit most of the proteases, after protease inhibitor $\mathrm{K}$ was added, the toxicity effect of the supernatant was greatly reduced, and the mortality of treated $O$. formosanus was almost the same as that of the control. At the same time, the toxicity effects of the supernatants treated with the three types of protease inhibitors, PMSF, EDTA and 1,10-phenanthroline, were also reduced. At $48 \mathrm{~h}$, the corrected mortality rate of each treatment group was less than $32 \%$. These results indicate that there was more than one insecticidal protease in the supernatant and that these insecticidal proteins were one of the important causes of termite death.

Since both protease inhibitors EDTA and 1,10-phenanthroline inhibit metalloprotease, the supernatants treated with these inhibitors were incubated with $0.5 \mathrm{mmol} / \mathrm{L} \mathrm{ZnSO}_{4}$ for $1 \mathrm{~h}$ at $22{ }^{\circ} \mathrm{C}$ to confirm whether or not the metalloprotease was active. The results show that the insecticidal activity of the supernatant was restored after the $\mathrm{ZnSO}_{4}$ recovery experiment, which indicated that the metalloprotease was present in the supernatant and the insecticidal protease had a good toxicity effect on $O$. formosanus. However, this experiment only preliminarily confirmed that the active components of $S$. marcescens SM1 fermentation were metalloproteases and other proteins. More precise active components are not known and further investigation is necessary.

Open Access This article is licensed under a Creative Commons Attribution 4.0 International License, which permits use, sharing, adaptation, distribution and reproduction in any medium or format, as long as you give appropriate credit to the original author(s) and the source, provide a link to the Creative Commons licence, and indicate if changes were made. The images or other third party material in this article are included in the article's Creative Commons licence, unless indicated otherwise in a credit line to the material. If material is not included in the article's Creative Commons licence and your intended use is not permitted by statutory regulation or exceeds the permitted use, you will need to obtain permission directly from the copyright holder. To view a copy of this licence, visit http://creativecommons.org/licenses/by/4.0/.

\section{References}

Aggarwal C, Paul S, Tripathi V, Paul B, Khan MA (2017) Characterization of putative virulence factors of Serratia marcescens strain SEN for pathogenesis in Spodoptera litura. J Invertebr Pathol 143:115-123

Barloy F, Lecadet MM, Delécluse A (1998) Cloning and sequencing of three new putative toxin genes from Clostridium bifermentans CH18. Gene 211(2):293-299

Bowen D, Rocheleau TA, Blackburn M, Andreev O, Golubeva E, Bhartia R, Ffrench-Constant RH (1998) Insecticidal toxins from the bacterium Photorhabdus luminescens. Science 280:2129-2132

Chen XW, Fan H, Zhou K, Lan HX, Sun BZ (2005) Study on the toxicity of Serratia marcescens to the common vegetable insects. Tianjin Agric Sci 11:5-7

Cosme L, Turchen LM, Guedes RNC (2020) Chemical constituents of tropical woods and resistance to the invasive drywood termite Cryptotermes brevis. J Appl Entomol. https://doi.org/10.1111/ jen.12729

Dahlsjo CAL, Romero CSV, Iniguez CIE (2020) Termite diversity in ecuador: a comparison of two primary forest national parks. J Insect Sci. https://doi.org/10.1093/jisesa/iez129

Djuideu TCL, Bisseleua DHB, Kekeunou S, Meupia MJ, Difouo FG, Ambele CF (2020) Plant community composition and functional characteristics define invasion and infestation of termites in cocoa agroforestry systems. Agrofor Syst 94(1):185-201

Du H, Tong RL, Huang XY, Liu BR, Huang RM, Li ZQ (2020) Methoprene-induced genes in workers of Formosan subterranean termites (Coptotermes formosanus Shiraki). Insects. https://doi. org/10.3390/insects11020071

Forst S, Dowds B, Boemare N, Stackebrandt E (1997) Xenorhabdus and Photorhabdus spp.: bugs that kill bugs. Annu Rev Microbiol 51:47-72

Fu RJ, Qi XL, Feng K, Xia XR, Tang F (2019) Identification and characteristics of a strain of Serratia marcescens isolated from the termites, Odontotermes formosanus. J Nanjing For Univ Nat Sci Ed 43(1):76-82

Fu RJ, Zhou LX, Feng K, Lu XY, Luo J, Tang F (2020) Effects of Serratia marcescens (SM1) and its interaction with common biocontrol agents on the termite, Odontotermes formosanus. J For Res. https://doi.org/10.1007/S11676-020-01122-w

Hejazi A, Falkiner FR (1997) Serratia marcescens. J Med Microbiol 46(11):903-912

Hu ZH, Fang WW, Zhou XT, He W (2017) Killing effect of secondary metabolites of Serratia marcescens on Bursaphelenchus xylophilus. Jiangsu Agric Sci 45(19):183-186

Jin H, Ge SR, Tao Y, Ran HY, Liu SG (2005) Identification of a pathogenic strain of locusts and its toxicity and pathology. Acta Microbiol Sin 45:172-176

Li XS, Zeng JD, Lu BS, Xiao JJ (2008) Insecticidal effectivity of bacillus sphaericus to main daqu insect Alphitobius diaperinus Panzer. Agrochemicals 47(3):217-218

Liu J, Wang SW, Zhao K, Zhou DP (2010) Status quo and advances in bio-controlling termites. J Microbiol 30(2):91-94

McGaughey WH, Gould F, Gelernter W (1998) Bt resistance management. Nat Biotechnol 16(2):144-146

Montaner B, Perez-Tomas R (2003) The prodigiosins: a new family of anticancer drugs. Curr Cancer Drug Targets 3(1):57-65

Niu HT, Li LY, Liu BS, Guo HF (2015) Effect of temperature on pathogenicity of Serratia marcescens S-JS1 against Spodoptera exigua and Spodoptera litura. Southwest China J Agric Sci 28(6):2516-2520

Niu HT, Xiao LJJ, Wang N, Liu BS, Yu TC, Guo HF (2018) Combined effects of Serratia marcescens S-JS1 with five insecticides against 
Laodelphax striatellus and the effect of S-JS1 on activities of relative enzymes in L. striatellus. Chin J Pestic Sci 20(2):185-191

Patil CD, Patil SV, Salunke BK, Salunkhe RB (2011) Prodigiosin produced by Serratia marcescens NMCC46 as a mosquito larvicidal agent against Aedes aegypti and Anopheles stephensi. Parasitol Res 109:1179-1187

Rajamohan F, Lee MK, Dean DH (1998) Bacillus thuringiensis insecticidal proteins: molecular mode of action. Prog Nucleic Acid Res Mol Biol 60:1-27

Regev A, Keller M, Strizhov N, Sneh B, Prudovsky E, Chet I, Ginzberg I, Koncz-Kalman Z, Koncz C, Schell J, Zilberstein A (1996) Synergistic activity of a Bacillus thuringiensis $\delta$-endotoxin and a bacterial endochitinase against Spodoptera littoralis larvae. Appl Environ Microbiol 62:3581-3586

Sapkota R, Stout MJ, Henderson G (2020) Residual effects of termiticides on mortality of Formosan subterranean termite (Isoptera: Rhinotermitidae) on substrates subjected to flooding. J Econ Entomol 113(1):367-374

Schnepf E, Crickmore N, Van Rie J, Lereclus D, Baum J, Feitelson J, Zeigler DR, Dean DH (1998) Bacillus thuringiensis and its pesticidal crystal proteins. Microbiol Mol Biol Rev 62(3):775-806

Smigielski AJ, Akhurst RJ (1995) Toxin gene from Xenorhabdus nematophilus, US005972687A; WO 95/00647

Tang F, Cui L, Tang JG (2007) Difference in transmission efficiency to pesticides between Odontotermes formosanus (Shiraki) and Reticulitermes chinensis (Snyder). J Nanjing For Univ Nat Sci Ed 31(6):69-72

Tao K (2006) Studies on purification, gene cloning and expression of insecticidal protein. Doctoral dissertation. Sichuan University, Chengdu, China
Volgyi A, Fodor A, Szentirmai A, Forst S (1998) Phase variation in Xenorhabdus nematophilus. Appl Environ Microbiol 64(4):1188-1193

Xu HG, Peng HY (2004) Delayed effects of chitinase of Serratia marcesens $\mathrm{S}_{3}$ on Helicoverpa armigera in different instars. Acta Microbiol Sin 44:88-92

Yang JY, Ji CY, Ling B, Zhang MX (2014) Isolation and identification of bacteria from Phyllotreta striolata (Fabricius) and determination of its insecticidal bioactivity. Chin J Biol Control 30(3):434-440

Yin HX, Zhang J, Hou RT, Wang JD, Yang ZR (2004) Isolation and identification of a chitinase-producing bacterium and its synergistic effect on locust biocontrol. Plant Prot 30:37-41

Zhang YJ, Tan J, Lin YQ (2000) The effects on peritrophic membranes of Helicoverpa armigera treated by low temperature and chitinase. Chin J Biol Control 16:152-155

Zhang J, Qin WQ, Yan W, Peng ZQ (2011) Isolation and identification of a pathogenic strain of Rhynchophorus ferrugineus Oliver. Chin J Trop Crops 32(12):2331-2335

Zhang XW, Ji BZ, Liu SW, Cao DD, Yang JJ, Liu JJ, Ji SL, Soleymaninejadian E, Wang HJ (2015) Research progress inanatomic structures of digestive system and symbiotes in termites. J Nanjing For Univ Nat Sci Ed 39(1):155-161

Publisher's Note Springer Nature remains neutral with regard to jurisdictional claims in published maps and institutional affiliations. 